\title{
Obituary
}

\section{Prof. Frank Cavers}

$\mathrm{P}$ ROF. FRANK CAVERS, whose premature death occurred on May 26, was educated as a botanist at the University of Leeds, under the stimulating influence of the late Prof. Miall, whose heuristic methods attracted much attention in the early years of the century. After leaving the University, Cavers held teaching posts in botany at Hartley College, Southampton, and later at the Goldsmiths' College in London. He was not, however, in all respects well fitted for such work, though he was an excellent botanist and a most lucid expositor of his subject, as was shown by a number of elementary text-books -models of their kind-written for the University Correspondence College. He made a special study of the Bryophyta, publishing the results of his admirable researches in the Annals of Botany, the New Phytologist, and elsewhere, and obtaining the D.Sc. degree of the University of London.

On leaving the teaching profession, Cavers decided to qualify as a medical man, and after a hard struggle and several set-backs, eventually obtained his qualification. This part of his career furnished striking evidence of Cavers' grit and persistence, for to pursue the medical curriculum is not the easiest of tasks many years after normal student days have been left behind, and the mind has long been running in other channels. Once qualified, he made a thorough success of his job, taking a panel and private practice in the north of London, working extremely hard, and in less than ten years saving enough money to enable him to retire.
Besides his research, Cavers rendered other services to science. For a short time he was assistant editor of the New Phytologist, and on the formation of the British Ecological Society in 1913-in which he played an important part-he became its first secretary, and edited the Journal of Ecology from 1913 until 1916. In this work he showed his conspicuous powers of masterly condensation and clear exposition. His abstracts of voluminous papers dealing with complicated material were about as good as they could be. The same gifts were later afforded ample scope during his editorship of the Journal of Cancer Research, which he undertook on his retirement from medical practice.

Cavers was an extremely hard, untiring worker and the most modest and unselfish of colleagues, always ready and willing to do his share, and more than his share, of the work in hand. He was also a pleasant companion with wide cultural interests-altogether a very lovable man.

A. G. T.

WE regret to announce the following deaths:

Prof. A. A. Bowman, professor of moral philosophy in the University of Glasgow, on June 12, aged fiftythree years.

Sir George Hadcock, K.B.E., F.R.S., director of Vickers-Armstrongs, Ltd., and of Armstrong Whitworth, on June 4, aged seventy-five years.

Prof. Charles A. King, principal of the Engineering College, and Jodhpur Hardinge professor of technology in the Benares Hindu University since 1919, on May 19.

\section{News and Views}

\section{Total Solar Eclipse of June 19}

By the time this note appears in print, the parties stationed at various points on the long belt of totality will know whether atmospheric conditions have enabled them to carry out their eclipse programmes, or whether the many months of organisation and preparation have been in vain. Certain preliminary reports will, we hope, be available for publication in our next issue. An outline of the plans of the various expeditions was given in an article in NATURE of April 25, p. 685. Starting from Greece in southeasterm Europe, expeditions are stationed in Asia Minor, the Caucasus, at various places in Siberia, in Manchukuo and in Japan. One party sent by the Joint Permanent Eclipse Committee of the Royal Society and the Royal Astronomical Society, under the leadership of Prof. F. J. M. Stratton, has set up its apparatus at Hamishari in Hokkaido; the other British expedition, under Prof. J. A. Carroll, is at Omsk. We understand from Dr. T. Banachiewicz, of the Cracow Observatory, that four Polish expeditions are observing the eclipse, paying particular attention to Baily's beads ; one is in Japan, at Tsubetsu, one in the region of Omsk, and two in Greece (one on the island of Chios and one in the vicinity of Athens). All four expeditions are using similar chrono-cine. matographical instruments with neon tubes constructed at the Cracow Observatory. Prof. B. Gerasimovič, writing from the Eclipse Camp at Ak Boulak, near Orenburg, informs us that there are no less than twelve foreign parties and twenty-eight Soviet expeditions observing the eclipse from the U.S.S.R. The observing parties are stationed at Beloretchenskaya (North Caucasus). Ak Boulak (near Orenburg), Sara (near Orenburg), Kustanay, Omsk, Krasnojarsk and Botchkarevo (Far East). Prof. Gerasimovič has kindly undertaken to cable to NATURE a brief statement of results obtained from these stations, and we are also expecting to have a similar communication from Prof. Stratton. 